\title{
Numerical analysis of torsional tangent rigidity of reinforced concrete waffle slab
}

\section{Análise numérica da rigidez tangente à torção de laje nervurada de concreto armado}

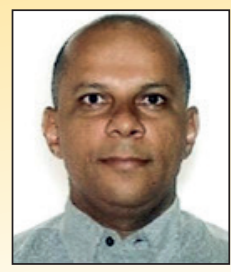

C. C. NUNES

claudiocruznunes@gmail.com https://orcid.org/0000-0002-7202-9967

\begin{abstract}
This research work deals with the analysis of torsional tangent rigidity of reinforced concrete waffle slabs by comparisons of the numerical analysis with results of experimental tests, with calculations performed using the ATENA program. This program was specially developed for the calculation of reinforced concrete structures, considering the physical and geometric nonlinear analysis using the finite element method. Numerical analysis considered the tensile strength of the concrete and consequently the fracture energy. Numerical situations were tested to obtain the calibration of the numerical analysis with the laboratory tests. After the calibrations, the results were extrapolated to extreme situations to infer tangent torsion rigidity in new situations. It is concluded that, for waffle slabs, near the rupture, the torsional tangent rigidity should be $5 \%$ of the torsional tangent rigidity to the initial torsion. In service, considering one third of the total breaking load, the torsional tangent rigidity should be $85 \%$ of the torsional tangent rigidity to the initial twist. This great torsional tangent rigidity in service is another parameter that guarantees the structural efficiency of the waffle slabs and can be used in the most diverse applications of structural engineering.
\end{abstract}

Keywords: reinforced concrete waffle slab, torsional tangent rigidity, numerical analysis.

\section{Resumo}

Este trabalho de investigação científica aborda a análise da rigidez tangente à torção de lajes nervuradas de concreto armado por meio de comparações da análise numérica com resultados de ensaios experimentais, cujo cálculo foi feito no programa ATENA. Tal programa foi desenvolvido especialmente para cálculo de estruturas de concreto armado considerando de forma ampla a análise não linear física e geométrica com uso do método dos elementos finitos. As analises numéricas levaram em consideração a resistência à tração do concreto e consequentemente a energia de fratura. Diversas situações numéricas foram testadas para se obter a calibragem da análise numérica com os ensaios de laboratório. Após as calibragens, os resultados foram extrapolados para as situações extremas para se inferir sobre a rigidez tangente à torção em novas situações. Conclui-se que, para lajes nervuradas, nas proximidades da ruptura, a rigidez tangente à torção deve ser $5 \%$ da rigidez tangente à torção inicial. Em serviço, considerando um terço da carga total de ruptura, a rigidez tangente à torção deve ser $85 \%$ da rigidez tangente à torção inicial. Essa grande rigidez tangente à torção em serviço é mais um parâmetro que garante a eficiência estrutural das lajes nervuradas, podendo ser usadas nas mais diversas aplicações arrojadas de engenharia estrutural.

Palavras-chave: laje nervurada de concreto armado, rigidez tangente à torção, análise numérica.

\footnotetext{
Federal University of Mato Grosso, Faculty of Architecture, Engineering and Technology, Department of Civil Engineering, Cuiabá, MT, Brazil.
} 


\section{Introduction}

The waffle slab is a system that has lower costs, so it has become widely used. Albuquerque [1] showed that for the region of São Paulo, the waffle reinforced concrete slab with propylene crates has a cost of $15.15 \%$ less than the solid slab of reinforced concrete, using both a traditional framework. The same author also concluded that the flat waffle slab of reinforced concrete with a propylene crates costs $7.84 \%$ less than the solid slab with traditional framework. The use of flat slab brings the structural disadvantage of not forming frame structures due to the few beams or absence of them. Therefore, its use in buildings generally relies on geometric nonlinear analysis.

Nunes and Lima [2] showed that a ten-story building with flat waffle slab of reinforced concrete already exhibits high-rise behavior. The building was calculated in the linear regime and also in the nonlinear geometric regime, with geometric nonlinear formulation developed by Nunes [3] and Nunes et al. [4], and with generalized linear relationship among displacements, with formulation developed by Nunes [5] and Soriano and Nunes [6] The building presented differences of $103.54 \%$ in the moments and $47.5 \%$ in the top displacements, between the linear and non-linear geometric analysis. In this calculation, the slab was considered as a rigid diaphragm and the rigidity was not computed. However, the bending stiffness of the slab can be computed considering slab strips when having pillars aligned in rows, as proposed by Lúcio [7].

This simplification is allowed by ABNT NBR 6118: 2014 [8] and some researchers adopt it in their articles like Galeb and Atiyah [9]. However, the waffle slab also has other rigidities, such as torsion, which are better computed when adopting a grid mesh in conjunction with the space frame of the pillars and beams or discretizing the waffle slab with shell finite elements, with an equivalent thickness of solid slab, together with the space frame of the pillars and beams. The major question in whether to discretize the slab as a grid or as an equivalent thickness of massive slab is how much the torsional rigidity for each case should be. The torsional rigidity is a difficult physical data to be generically established for use in all structural elements. Therefore, there are many studies and disagreement about the procedures as torsional rigidity is established for particular cases, as in the case of waffle slabs.

Stramandinoli and Loriggio [10], [11] propose the grid analogy to calculate the waffle slabs. They claim that simulating the waffle slab as massive has provided unsatisfactory results in a number of cases. The grid analogy is contested by Araújo [12], as it does not provide satisfactory results in several situations. Araujo [12] considers that the waffle slabs, to have great torsional rigidity, must be calculated as solid slabs of equivalent thickness. According to Araujo [12] (p.1), "when the (waffle) slab is cross-armed, the results are very dependent on the slab's torsional rigidity and at this point there is no consensus as to which values to adopt". But Araújo himself [12], [13] presents good approximations that can be made, considering an equivalent thickness of massive slab. However, these simplifications, whether considering a massive slab, which is more precise, or for the grid analogy, will always lead to approximate results that will require calibration.
Another way of calculating the waffle slabs is with the use of finite elements. In this case, shell elements can be used to discretize the cap as well as the ribs (RECALDE et al. [14]). This model maintains all the plate compatibilities developed by the cover and also computes the bends and the twists of the cover and the ribs. Other researchers have adopted more advanced models to consider concrete cracking as can be seen in Lima et al. [15]. One can even adopt the non-perfect adhesion between steel and concrete, as done by Tavares et al. [16] in the numerical simulation of pullout tests. Another way is to use three-dimensional finite elements to discretize the entire shell and ribs. The finite element method is highly recommended for those considering the nonlinear effects of concrete and reinforcement. The latter is the method that was used in this work. The disadvantage of these methods is the high computational cost, as already observed by Parente Jr et al. [17] even in portico analysis, and the need for detailed discretization of the finite element mesh in critical regions as can be seen in Marasca et al. [18]. All this makes these advanced methods little used in projects, but they are mandatory for advanced research studies, especially when comparisons are made with experimental tests.

According to ABNT NBR 6118: 2014 (p.97) [8], "Unidirectional waffle slabs should be calculated according to the direction of the ribs, neglecting transverse stiffness and torsional stiffness." As for cross waffle slabs, ABNT NBR 6118: 2014 (p. 97) [8] states that: "Bidirectional waffle slabs ... can be calculated, for the purpose of demanding efforts, as massive slabs" (Our italics).

Another physical parameter that greatly interferes in the physical nonlinear calculation is the tensile strength of the concrete and the variables dependent on it. "In a manner analogous to the compressive strength, the tensile strength of the concrete presents a significant variability around an average value. In general, this variability is greater than that found for compressive strength "(ARAÚJO, [19], p.1). This greater dispersion around the mean for the tensile strength of the concrete may be a great uncertainty factor for stipulating a fixed value in a deterministic calculation to be compared with laboratory testing.

The constitutive relationship - tension versus deformation - of the drawn concrete has an ascending phase, a peak and a descending phase. The upward part has a longitudinal modulus of elasticity similar to that of compression. It presents little non-linearity and can generally be adopted as linear. After the peak tension, cracking damages in the weaker parts of the concrete begin to occur. After this phenomenon, the problem is no longer the mechanics of the continuum. Therefore, after the cracking, a stress versus crack opening diagram is adopted. The area under this diagram and the abscissa axis, corresponding to the crack opening, is defined as specific fracture energy - $\mathrm{Gf}$ - energy required to create a complete crack of unit area (ARAÚJO [19]).

Several test methods can be used to determine fracture energy. The method depends on the mode of fracture to be analyzed (ARAÚJO, [19]). Fernández-Canteli et al. [20], in order to determine the fracture energy, calculate the work performed by the force that causes the fracture versus the displacement corresponding to the fracture opening, then define the fracture energy as the ratio between that work and the area of fracture bonding. Hillerborg (apud Araújo [19]), in a study conducted with a series of tests, found that the fracture 
energy depends on a number of factors, such as concrete composition, curing conditions, age, etc. He found no correlation, but concluded that the fracture energy increases with the size of the coarse aggregate. The fracture energy also depends on the size of the fracture in relation to the grain of the materials and the size of the samples. Some researchers, such as Bazant and Kazemi [21] and Abdalla and Karihaloo [22], have developed formulations to measure fracture energy independent of some of these dimensions. According to Lee and Lopez [23], the test methods also interfere in the measurement of fracture energy. They propose a bilinear method to simulate the fracture energy curve and determine the value of it, as recommended by codes such as CEB-FIP 2010 [24].

Other mathematical models are also used to define fracture energy such as Hillerborg's linear law (apud SILVA NETO [25]) and Xu's exponential law (apud SILVA NETO [25]). Fernández-Canteli et al. [20] demonstrated that when comparing test results with those of numerical analyzes, the types of discretization and boundary prescriptions (supports) of the numerical models interfere with the results. These authors demonstrated that the results of modified compact tension test (MCT), compared to numerical analysis calculated with finite elements in the commercial programs ABAQUS and ATENA, showed good results, confirming its practical usability. According to Fernández-Canteli et al. [20], 3D calculations are unavoidable for proper numerical simulation of the actual test conditions, in order to obtain a true fracture energy value of the concrete.

The fib Model Code for Concrete Structures 2010 (fib - CEB-FIP, page 78, [24]) adopts fracture energy independent of aggregate and other factors, simply defining $G_{f}=73 f_{c m}{ }^{\wedge 0,18}$. The ATENA program, used in this work, calculates the fracture energy by a different formula given by $G_{f}=0,000025 f_{t}{ }^{\prime}$ ef $(M N / m)$ (ČERVENKA, p. 20 e 33, [26]). These simplifications and differences in fracture energy

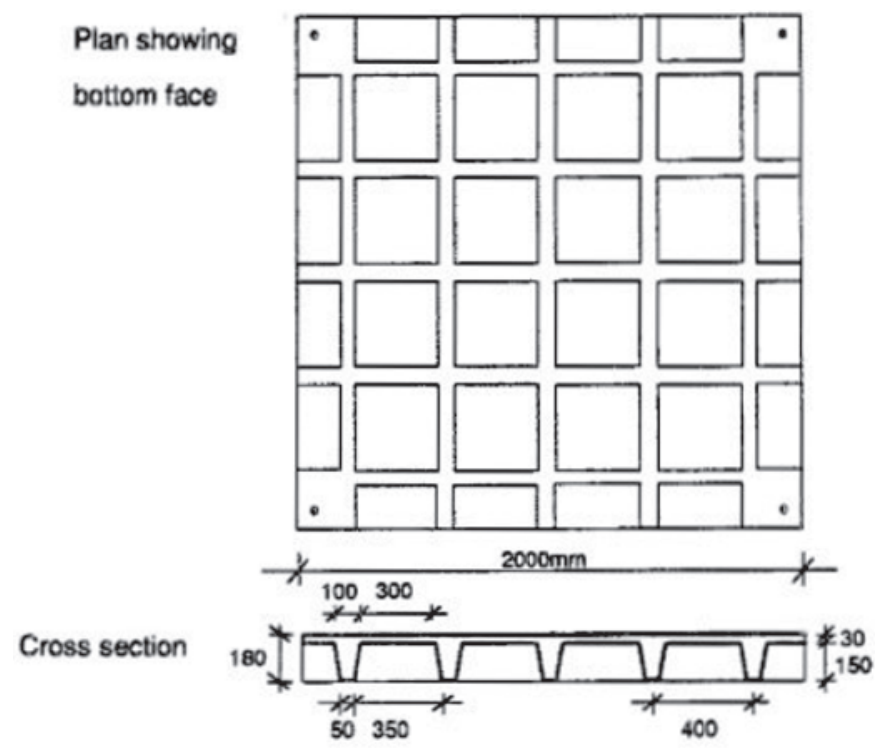

Dimensions of the models VL3A and VL3B.

\section{Figure 1}

Dimensions of the VL3A and VL3B models

Source: Lúcio [7] formulation, which depend on the tensile strength of the concrete and other factors such as aggregate type, are complication factors in advanced analyzes performed in the physical and geometric nonlinear regime for comparisons with laboratory tests.

Therefore, this research aims to verify if the rigidity of the waffle slab to the torsion has or does not have significant values in service as well as in the rupture. It is assumed that torsional rigidity depends on several factors such as tensile strength of the concrete and consequently the fracture energy of the concrete. The study is carried out by means of comparisons of some experimental results with models calculated through numerical analysis in the ATENA program, in the physical and geometric nonlinear regime, using the finite element three-dimensional method.

\section{Methodology}

\subsection{Materials}

For the development of this scientific research the following materials were used: Experimental results of Lúcio's PhD Thesis [7]; physical and geometric non-linear analysis program for reinforced concrete ATENA, of the Červenka Consulting s.r.o. [27], high performance computer with 16 GB of RAM and 12 processors from the Faculty of Science and Technology of the New University of Lisbon, Lisbon - Portugal; notebook with i5 processor and $8 \mathrm{~GB}$ of RAM; spreadsheet and text editor.

\subsection{Method}

The initial construction of the models was done directly in the ATENA program, using notebook i5. These models were refined with finite element meshes through the various macroelements, corresponding to the data preprocessing phase. Later, the models were executed in the high performance computer, in which one can process several models, even from different researches, simultaneously. The post-processing phase was developed in the i5 notebook using the ATENA program and electronic spreadsheets for graphing in order to compare numerical and experimental results.

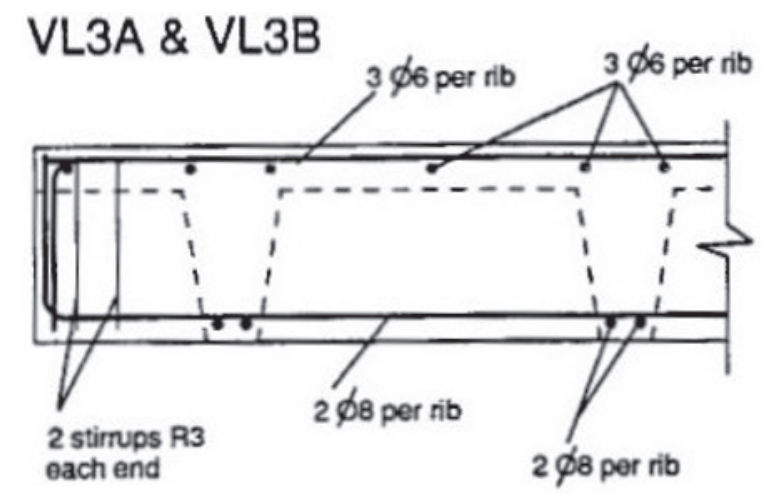

\section{Reinforcement of the models.}

\section{Figure 2}

Reinforcement of the models

Source: Lúcio [7] 


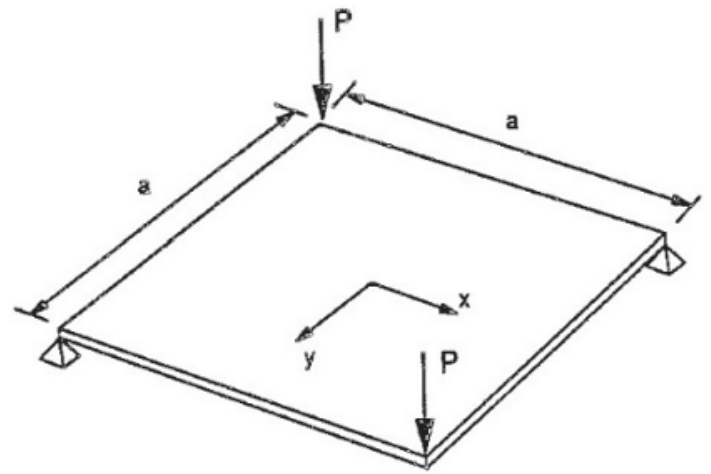

Figure 3

Load sketch and support for twist test

of the waffle slab

Source: Lúcio [7]

\section{Laboratory test used as reference}

The laboratory tests used as reference for this work were performed by Lúcio [7] in his $\mathrm{PhD}$ thesis. The results of the tests were used for direct comparisons of results and calibration of the numerical model. Figure 1 shows the dimensions of the waffle slabs and Figure 2 shows the reinforcement of the models. The tests were performed according to the outline of Figure 3. Details of test equipment can be seen in the outline presented in Figure 4 With this scheme, the slab is requested to twist. Table 1 shows the mechanical properties of the concrete used in the construction of the slabs. The properties are practically based on cube tests, from

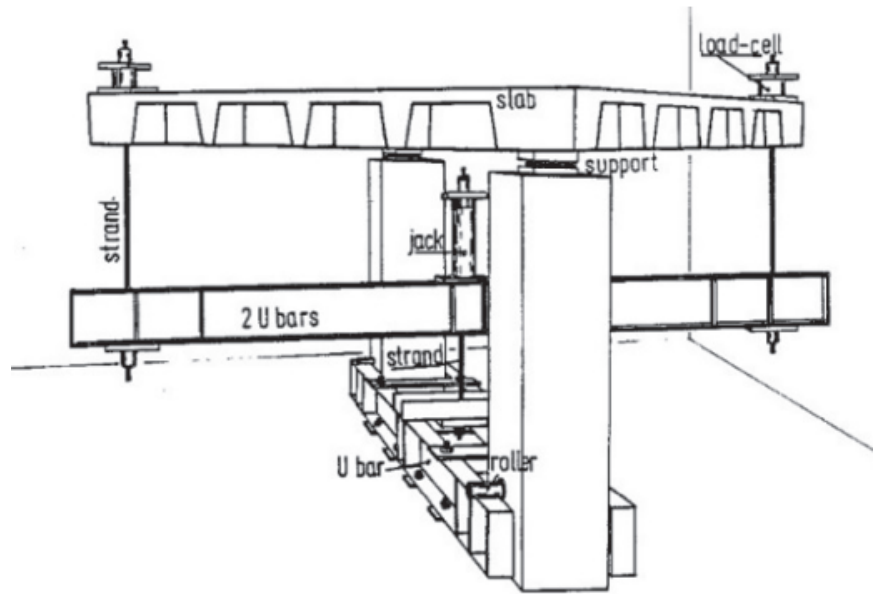

Test of models VL3A and VL3B.

\section{Figure 4}

Details of the scheme for twist test of the waffle slab Source: Lúcio [7]

which the $f_{c u}$ is obtained. With this parameter, the other mechanical properties are calculated. Other properties that were required for the numerical analysis will be presented later. Table 2 shows the mechanical properties of the reinforcement used in the slabs.

From the sketch in Figure 3, it is shown that the torque of the load applied in the test is given by Equation 1.

$\boldsymbol{m}_{x y}=\frac{P}{2}$

Where: $\mathrm{m}_{\mathrm{xy}}$ is the twisting moment and $\mathrm{P}$ is the load applied.

\section{Table 1}

Mechanical properties of the concrete of the waffle slabs calculated with formulas of the time of the test

\begin{tabular}{cccc}
\hline Slab & $\begin{array}{c}\text { Test age } \\
{[\text { days }]}\end{array}$ & $\begin{array}{c}\mathbf{f}_{\mathrm{cu}} \\
{\left[\mathbf{N} / \mathbf{m m}^{2}\right]}\end{array}$ & $\begin{array}{c}\mathbf{f}_{\mathrm{sp}} \\
{\left[\mathbf{N} / \mathbf{m m}_{2}\right]}\end{array}$ \\
\hline VL1 & 16 & 37.4 & 3.1 \\
VL2 & 19 & 38.5 & - \\
VL3 & 21 & 38.2 & - \\
VL3A & 48 & 56.2 & 4.3 \\
VL3B & 32 & 50.1 & - \\
\hline
\end{tabular}

\begin{tabular}{|c|c|c|c|c|c|}
\hline \multicolumn{6}{|c|}{ Average values of the test results of the concrete specimens } \\
\hline Slab & $\begin{array}{c}\mathbf{f}_{\mathrm{c}} \\
{\left[\mathrm{N} / \mathrm{mm}^{2}\right]}\end{array}$ & $\begin{array}{c}E_{\mathrm{c}} \\
{\left[\mathrm{kN} / \mathrm{mm}^{2}\right]}\end{array}$ & $\begin{array}{c}\mathbf{G} \\
{\left[\mathrm{kN} / \mathrm{mm}^{2}\right]}\end{array}$ & $\begin{array}{c}\mathbf{f}_{\mathrm{sp}} \\
{\left[\mathrm{N} / \mathrm{mm}^{2}\right]}\end{array}$ & $\begin{array}{c}\mathbf{f}_{\mathrm{r}} \\
{\left[\mathrm{N} / \mathrm{mm}^{2}\right]}\end{array}$ \\
\hline VL1 & 31.0 & 25.6 & 10.7 & 3.1 & 4.5 \\
\hline VL2 & 32.0 & 26.0 & 10.8 & 3.2 & 4.6 \\
\hline VL3 & 31.7 & 25.9 & 10.8 & 3.2 & 4.6 \\
\hline VL3A & 46.6 & 31.4 & 13.1 & 4.3 & 6.2 \\
\hline VL3B & 41.6 & 29.7 & 12.4 & 3.8 & 5.5 \\
\hline \multicolumn{6}{|c|}{ - from $|57|: f_{c}=0.83 f_{c u}$} \\
\hline \multicolumn{6}{|c|}{ - from $|58|: \mathrm{E}_{\mathrm{c}}=4.6 \times 10^{3} \mathrm{f}_{\mathrm{c}}{ }^{1 / 2}\left[\mathrm{~N} / \mathrm{mm}^{2}\right]$} \\
\hline & & $-G=\frac{1}{2(1}$ & $v=0.2$ & & \\
\hline
\end{tabular}


Table 2

Mechanical properties of the reinforcement

\begin{tabular}{|c|c|c|c|}
\hline Type & Designation & $\begin{array}{c}\text { Diameter } \\
{[\mathrm{mm}]}\end{array}$ & $\begin{array}{l}\mathbf{f}_{\mathrm{sy}}=\sigma_{0.2 \%} \\
{\left[\mathrm{~N} / \mathrm{mm}^{2}\right]}\end{array}$ \\
\hline Plain round soft iron cold stretched & R3 & 3 & 273 \\
\hline \multirow{3}{*}{ Deformed hot rolled steel } & T6 & 6 & 585 \\
\hline & T8 & 8 & 500 \\
\hline & $\mathrm{T} 10$ & 10 & 548 \\
\hline \multirow{2}{*}{ High yield steel } & $\phi 6$ & 6 & 425 \\
\hline & $\phi 8$ & 8 & 525 \\
\hline
\end{tabular}

Source: Lúcio [7]

The twisting moment of the slab's own weight is given by Equation

2. For more details see Figure 5, (LÚClO [7]).

$m_{x y 0}=\frac{g a^{2}}{8}$

Where: $m_{x y 0}$ is the twisting moment of the slab's own weight, $g$ is the slab's own weight and a slab size.

In Figure 6, we have the axle systems and the measuring points of the vertical displacements. There is also the Mohr circle for transforming moments between coordinate systems. With the displacements of these points, the torsional curvature can be calculated with Equation 3.

$$
w_{x y}=\frac{-w_{2}+w_{3}+w_{4}-w_{5}}{c^{2}}
$$

Where: $w_{x y}$ is the torsional curvature; $w_{2}, w_{3}, w_{4}$ e $w_{5}$ are the displacements of the points of the slab marked in Figure 6 and $c$ is the horizontal and vertical distance between points.

Therefore, by definition, the torsional stiffness can be calculated by Equation 4, (LÚCIO [7]).

$D_{x y}=\frac{1}{2} \frac{m_{x y}}{w_{x y}}$

$$
m_{\xi 0}=-\frac{g a^{2}}{12} ; \quad m_{\eta 0}=\frac{g a^{2}}{6} ; \quad m_{x y 0}=\frac{g a^{2}}{8}
$$
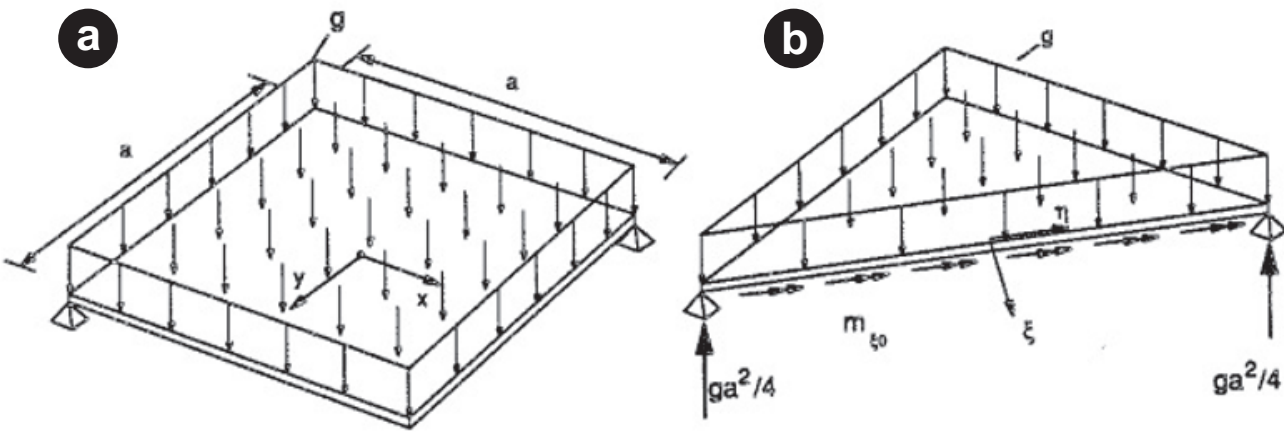

c

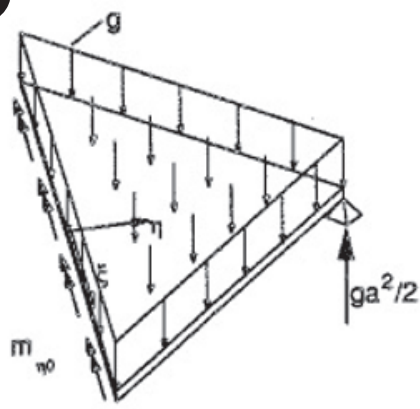

d

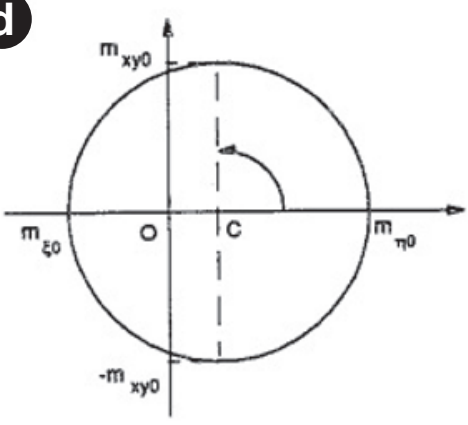

Influence of the self-weight of the model.

\section{Figure 5}

Influence of the self-weight at the moment of twisting

Source: Lúcio [7] 
a

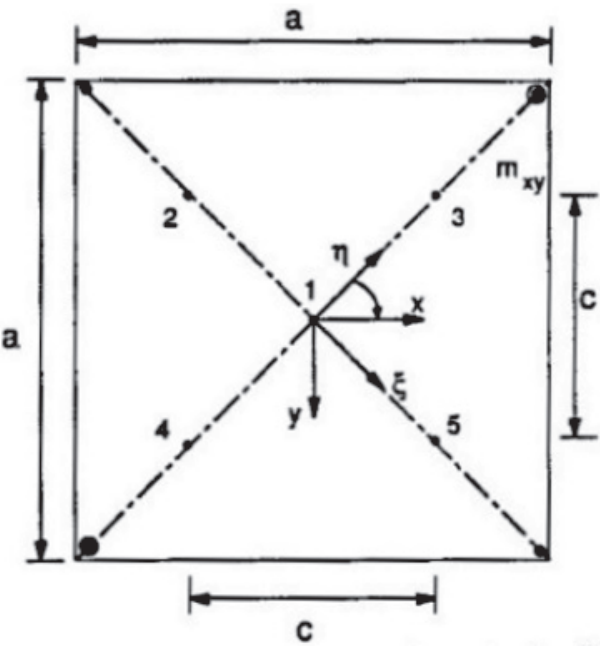

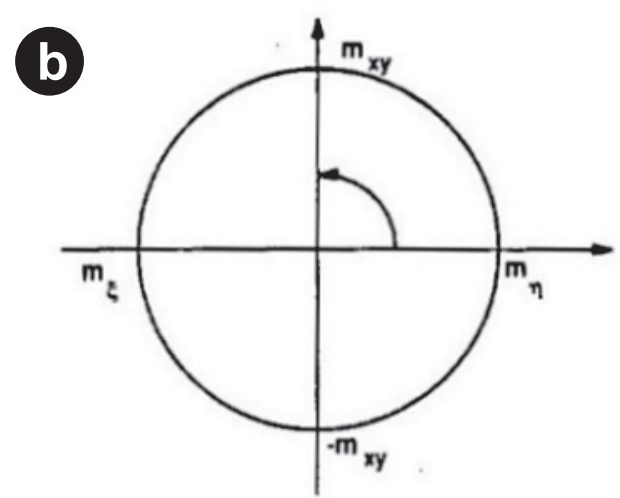

\section{Figure 6}

Axis system, vertical displacement measuring points and Mohr circle

Source: Lúcio [7]

Where: $D_{x y}$ is the torsional stiffness, $m_{x y}$ is the total twisting moment and $\mathrm{w}_{\mathrm{xy}}$ is the torsional curvature.

\section{Numerical analysis}

The ATENA models are basically constructed using macroelements (ČERVENKA, [28]). A complex model can be fragmented into many simple macroelements. Initially, a macroelement of a portion of the rib was generated. Subsequently, this macroelement was copied systematically to generate the ribs. Next, the macroelement was generated for the cover, then for the support plates at the top and corners of the cover, and finally for the fillers of the corners. In Figure 1 and Figure 7, the ribs are found to be of varying thickness along the height. Rounding between the edges of the rib surfaces and between the ribs and the cover of the actual models was not discretized in the numerical models.

The four support plates were considered linear elastic to avoid stress concentrations at the bearing points and the load insertion

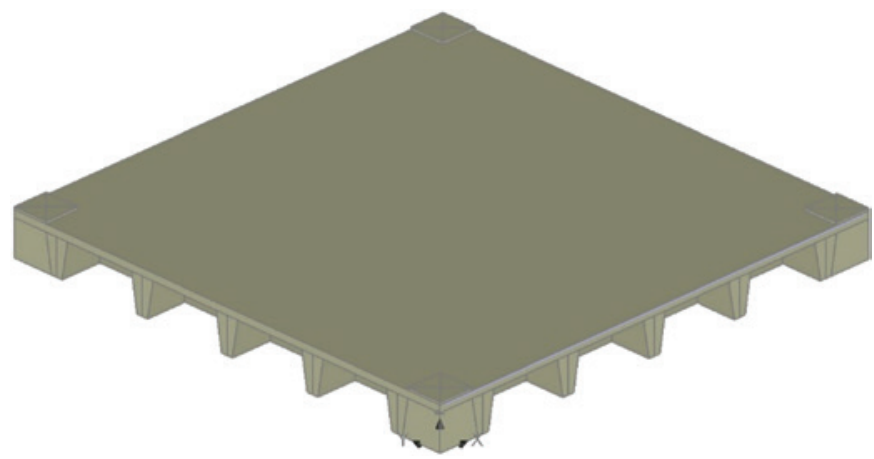

\section{Figure 7}

Numerical model with ribs, corner fillers, cover and support plates discretized with macroelements points. The support plates were built in the numerical model with a thickness of $10 \mathrm{~mm}$. In Figure 7, we have the numerical model with the ribs, corner reinforcement fillers, cover plates and support plates discretized with macroelements. By means of the information in Figure 2, the reinforcements were discretized in the model developed in the ATENA.

It can be seen in Figure 2 that the lower and upper reinforcements have end folds that serve to anchor them in the concrete. As in the numerical model it was decided to use perfect adhesion between reinforcement and concrete, and these folds were not discretized. Thus, the reinforcements were discretized as straight lines in both the bottom of the ribs and the cover, see Figure 8. The reinforcements of different directions were discretized at different heights,

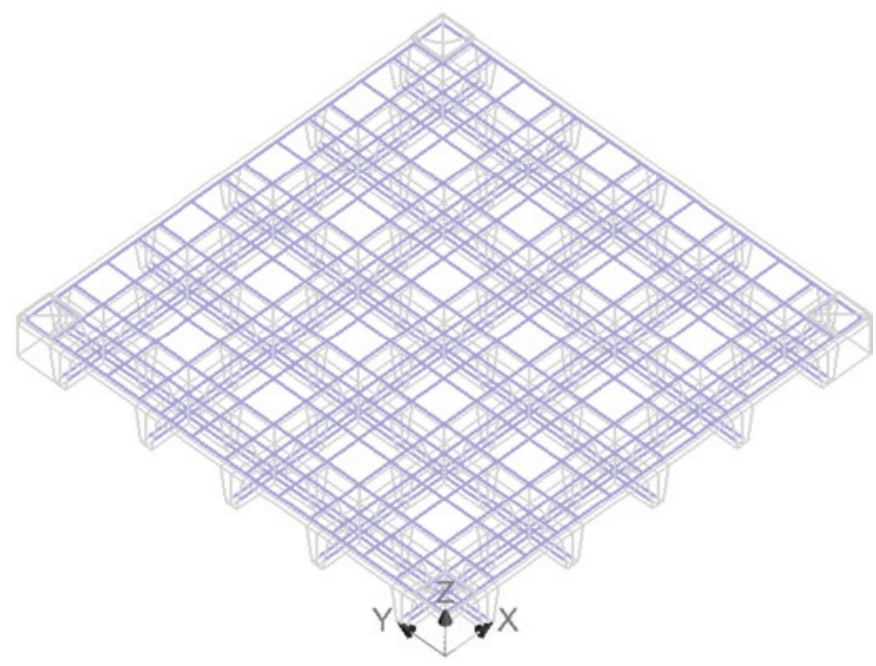

Figure 8

Reinforcement of the VL3A model discretized in the ATENA program 
respecting this detail that can be seen in Figure 2. This specificity is also important to make sure that the program, by discretizing finite element steel bars, which is done automatically, would not form a mesh like a welded mesh. In this way, it was guaranteed that the bars would work in isolation in the numerical model as it happened in the real model. It was also taken into account, in the numerical model, that the steel bars do not work the compression.

The finite element meshes are generated in the ATENA program by means of the macroelements and are automatically compatibilized with the finite element mesh of the steel bars. They can be generated together for all macroelements with global parameters, but meshes can also be generated for one or more macro elements at a time. It is also possible to refine the discretization for a macro element, a plane, a line or a point, by means of a semiautomatic refinement process.

In Figure 9, it can be seen that the slab cover is discretized with a different refinement of the ribs. This whole process can generate finite element meshes of incompatible nodes between the macro elements. As a result, it may occur that nodes in the contact planes between the macroelements may not coincide. As in the finite element method, the nodes between adjacent elements must be coincident, in order to prevent voids or material overlaps, the system uses dependence between displacements to make the finite element meshes compatible between the macroelements. These dependencies have several specific rules such as: number of nodes on counted surfaces between macro elements, whether the links are perfect or whether sliding is allowed. The surface that has fewer nodes has its nodes defined as master and the other has its nodes defined as dependent nodes. These dependency rules related to the number of nodes are calculated automatically by the program, and the user can interfere in some parameters (ČERVENKA, [28]). For the development of the meshes, perfect bonds were adopted in the contact surfaces between the macroelements, made compatible by means of dependence between displacements. The type of the dependency matrix between displacements is defined internally by the program.

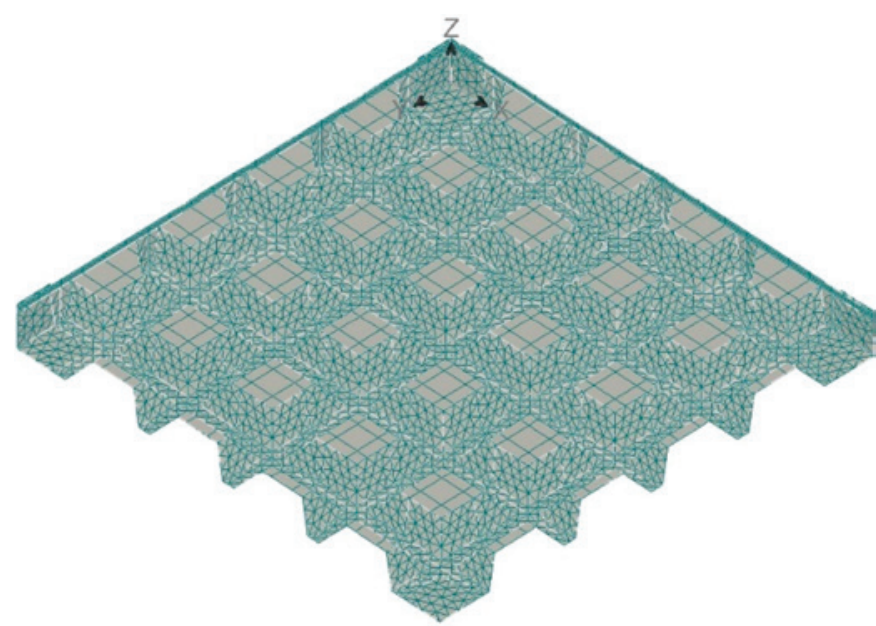

\section{Figure 9}

Finite element mesh for the VL3A model with 22,278 finite elements
To obtain finite element meshes suitable for processing, various combinations of meshes were studied and tested. Meshes with more than 80,000 finite elements presented problems of convergence and took more than eight hours of processing. The meshes between 40,000 and 80,0000 elements presented convergence to one situation but errors of convergence to others, with small changes of physical or geometric parameter and took about three hours of processing. Nevertheless, the meshes with less than 40,000 finite elements, presented convergence without errors and took less processing time, about one hour. For meshes with less than 20,000 finite elements there was a processing of less than an hour, but they did not have an adequate convergence.

All this occurs because the finite element method can not have a very small number of elements for a complex geometry, since the method is approximate. On the other hand, an excessive number of finite elements makes the vectors of load and displacement very large, making it difficult to verify convergence for a very complex problem.

From this, it can be concluded, at this stage, that we should use meshes between 20,000 and 40,000 finite elements. This preliminary conclusion in the number of finite elements cannot be extrapolated to all problems, since each case must be studied separately when using semiautomatic refinement. To improve the discretization in specific locations, without increasing the number of finite elements, different refinement was used, according to the type of macro element. For the ribs, the number of adequate finite elements along the height and the finite element type were studied, since ATENA has several finite element types (ČERVENKA, [28]). For the cover, we also studied the amount of finite elements that would be adequate along the thickness and width. The mesh shown in Figure 9, for example, is a mesh that was considered suitable. This mesh is of the VL3A model and has 22,278 finite elements, having three finite elements along the height of the vein, of the tetrahedron type, and four along the thickness of the slab, of the quadrilateral side prism type, obtained through semi-automatic discretization.

The finite element meshes of the macroelements are defined in the pre-processing phase. However, the steel bars are automatically discretized in finite elements in the processing phase, where the program creates a finite element mesh for the steel bars compatible with the finite element mesh of the macroelements. Thus, the user does not interfere in the creation of the finite element mesh of steel bars, (ČERVENKA, [28]).

The application of the loads involves a process of support configuration change throughout the calculation process. To simulate the test situation of Figure 4, in the application of the self-weight it was initially considered that two diagonally opposed supports are fixed and the other two are free. With this, the situation of fixing the waffle slab on the two supports in the pillar form of Figure 4 is numerically simulated. Afterwards, two diagonally opposing supports are introduced, leaving the slab with four supports and its own weight already applied in the two initial supports. The loads of Figure 3 are then introduced by means of displacements prescribed in the last two supports introduced. All this was possible in the numerical model because ATENA (ČERVENKA, [28]) allows to change and combine different situations of supports and loads throughout the calculation process. In this way, the situations that occurred in the test were simulated numerically as closely as possible. 


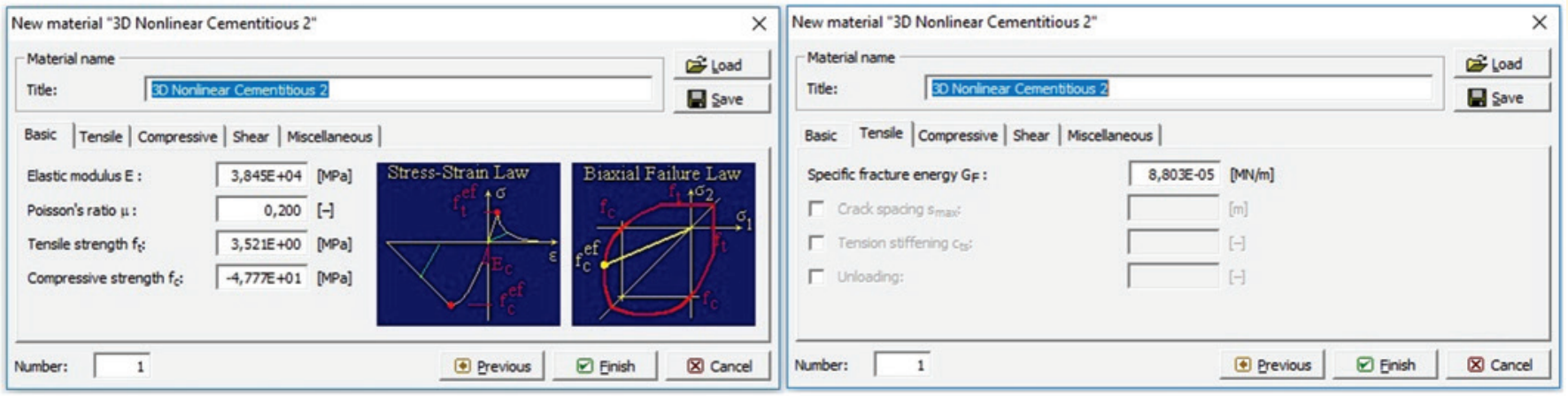

Figure 10

Concrete properties calculated by ATENA for $\mathrm{f}_{\mathrm{c}, \text { cube }}=56.2 \mathrm{MPa}$ for model VL3A

In order to approach the nonlinear problem, the current ATENA method was used, which is the Updated Lagrangian formulation. For the numerical solution of the non-linear algebraic equations the Newton-Raphson method was used with corrections of the stiffness matrix in all iterations. In this case the computational cost is higher, but there is a convergence facility in relation to the modified method, in which the stiffness matrix is corrected only at the beginning of each increment. (ČERVENKA, p. 2, 199-201, [26])

The weight itself was introduced in four steps because it is a little non-linear phase. The test load, introduced by means of prescribed displacement, had to be placed with many more steps, that is, 24 to 34 loading steps. Increments with more steps, around 100, generated convergence errors and increments with fewer steps resulted in data with significant errors. Through these tests, this range of steps was adopted for the processing.

Since the nonlinear analysis generates a very large amount of data, monitoring points were defined (ČERVENKA, p. 99, [28]). The points of support and the numbered points of Figure 6 were defined as monitoring points, since at these points the experimental measurements were made. In this way, the program already separates data for these points, making it possible to follow the graphical analysis in the processing phase, besides permitting the visualization of tensions and fractures. With the data of the monitoring points, in the post-processing phase, one can construct graphs with the ATENA itself or with electronic spreadsheets.

\section{Comparison between experimental and numerical analysis}

The ATENA program (ČERVENKA, [28]) requires only some initial properties to automatically calculate the mechanical properties of materials. For the calculation of concrete properties, the $f_{c, \text { cube }}$ is requested (ČERVENKA, p. 33, [26]). With this, the other properties are calculated automatically and those that do not depend on the $\mathrm{f}_{\mathrm{c}, \text { cube }}$ are also placed by the program, such as the specific weight of the concrete. For the reinforcing bars, a similar procedure also occurs, depending on the type of diagram that was chosen, in this case bilinear. The specific weight of steel is also placed by the program, as are other properties that are not indexed to a global parameter as the yield stress. After the automatic calculation of these properties, the user can change the properties. The main question is that the values calculated by the ATENA program for concrete properties as a function of $f_{c \text { cube }}$ are not all the same as those of the fib Model Code for Concrete Structures 2010 [24] and of the Portuguese Standard - Eurocode 2 [29]. With this, a very wide range of alternatives are opened that can be modified for the numerical calibration of the models.

In Table 1, we have the values of $f_{c, \text { cube }}$ (in case $f_{c u}$ ) and the mechanical properties of the concrete calculated as a function of $f_{c, \text { cube }}$ with the formulas at the time of the test (LÚCIO [7]).

The values of concrete properties calculated by ATENA for model $\mathrm{VL} 3 \mathrm{~A}, \mathrm{f}_{\mathrm{c}, \text { cube }}=56,2 \mathrm{MPa}$, can be seen in Figure 10. The program calculates properties other than those that are shown in Figure 10, see the tabs in the figure. However, as they were not changed in this search for the calibration of the numerical model, they are not presented in this text. The properties of concrete for the VL3B model, $\mathrm{f}_{\mathrm{c}, \text { cube }}=50,1 \mathrm{MPa}$, calculated by ATENA can be seen in Figure 11. However, the formulation used by the program can be found in ČERVENKA, p. 18, 25, 26 e 33, [26].

The values of the properties of the concrete calculated with the Portuguese Standard - Eurocode 2 - Design of concrete structures (p. 36, [29]) and the fracture energy of the concrete given by fib Model Code for Concrete Structures 2010 (fib - CEB-FIP, p. 78, [24]) can be seen in Table 3.
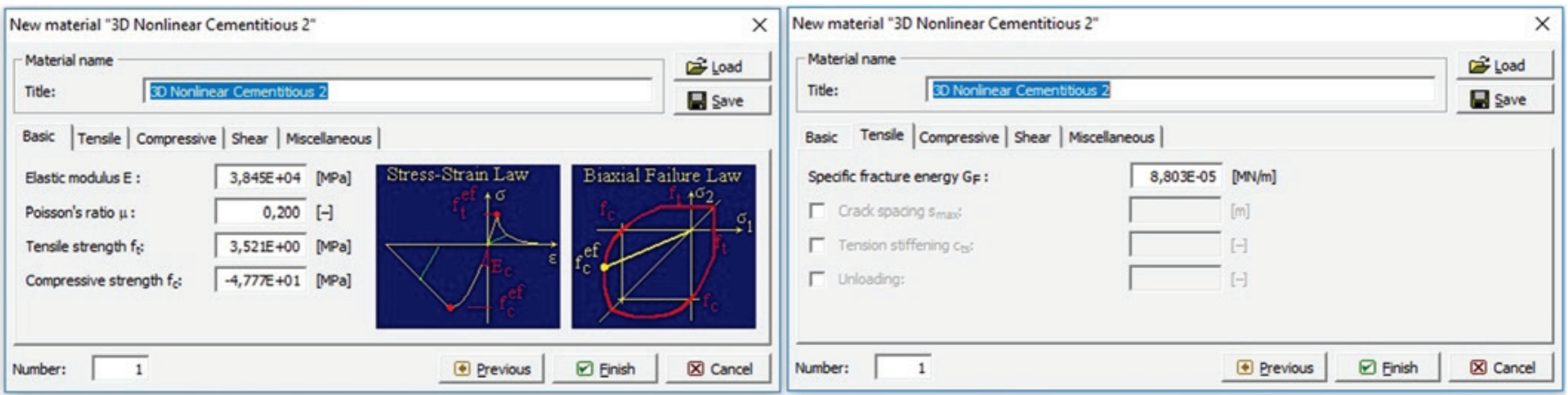

\section{Figure 11}

Concrete properties calculated by ATENA for $\mathrm{f}_{\mathrm{c}, \text { cube }}=50.1 \mathrm{MPa}$ for model VL3B 


\section{Table 3}

Mechanical properties of the concrete calculated with the Portuguese Standard - Eurocode 2 Concrete Structures Design (P. 36, [29]) and with the fib Model Code for Concrete Structures 2010 (fib - CEB-FIP, P. 78, [24])

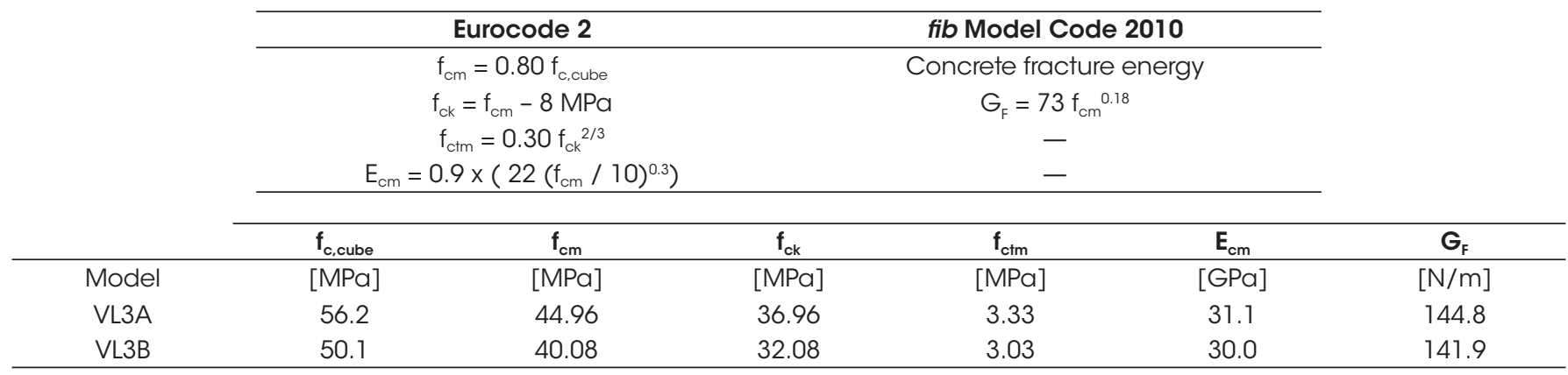

Comparing the values of concrete properties in Table 1 (calculated using the formulas at the time of the test) with Figure 10 and Figure 11 (calculated by ATENA) and Table 3, (calculated using Eurocode 2 [29] and fib Model Code for Concrete Structures 2010 [24]), there are several differences in values, especially in fracture energy. In the case of fracture energy, it is observed that the values

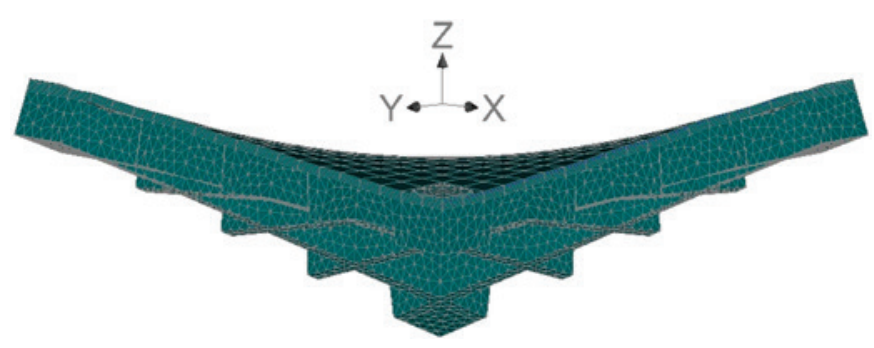

\section{Figure 12}

Deformed configuration, increased 50 -fold, of the waffle slab VL3A, calculated with 22,278 finite elements and 34 loading steps

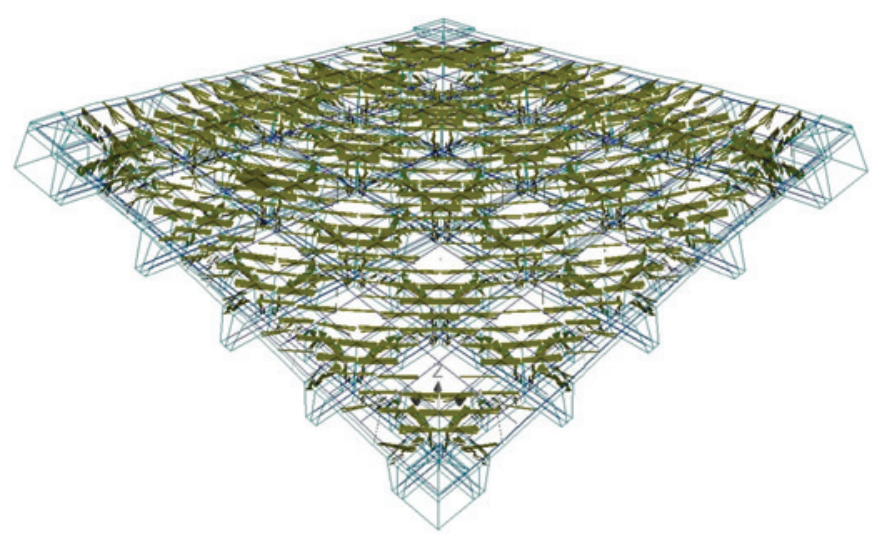

\section{Figure 13}

Cracks larger than $3 \mathrm{E}-5 \mathrm{~m}$ of the VL3A waffle slab cover, calculated with 22,278 finite elements and 34 loading steps calculated with Eurocode 2 [29] and fib Model Code for Concrete Structures 2010 [24], Table 3, are almost double those provided by ATENA, Figure 10 and Figure 11. All these differences open up a wide range of uncertainties and possibilities of adjustments for the calibration of the numerical models, to be compared with the tested models.

In Figure 12, there is the 50 -fold magnified deformed configuration of the VL3A waffle slab, calculated with 22,278 finite elements and 34 loading steps. It is noted there, that the deformed configuration is in saddle form. This ensures that the waffle slab will be urged to twist. In Figure 13, one can see the cracks of the VL3A slab cover calculated with the ATENA program. In Figure 14, one can see

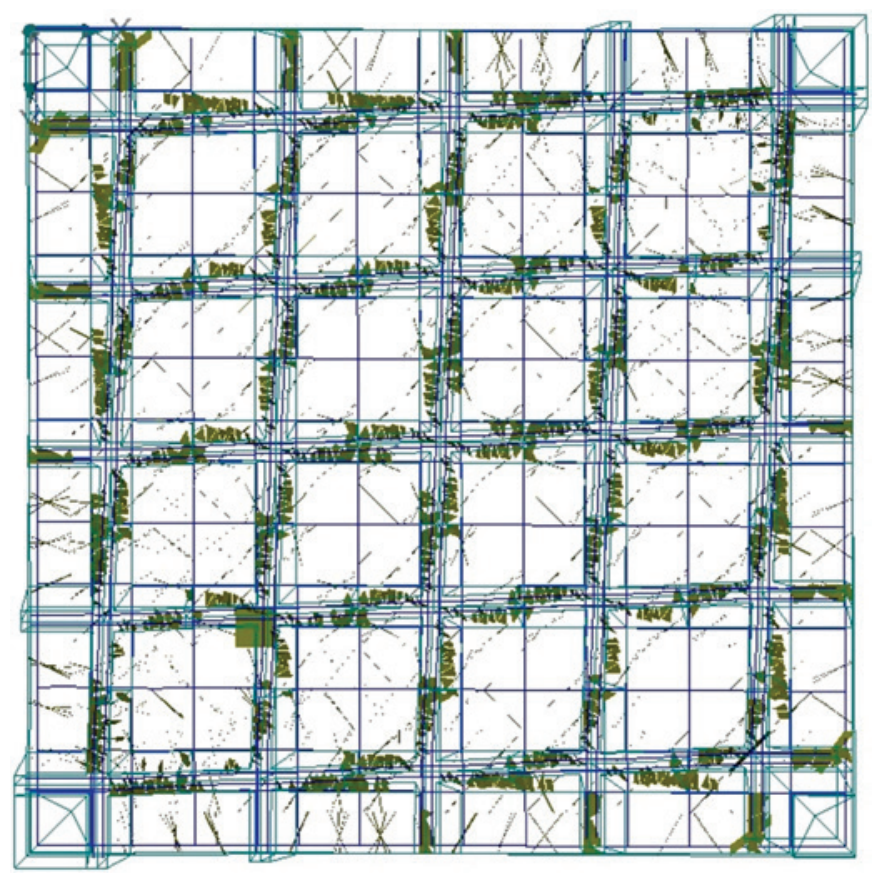

Figure 14

Cracks larger than $3 \mathrm{E}-5 \mathrm{~m}$ from the ribs of the VL3A waffle slab, calculated with 22,278 finite elements and 34 loading steps 


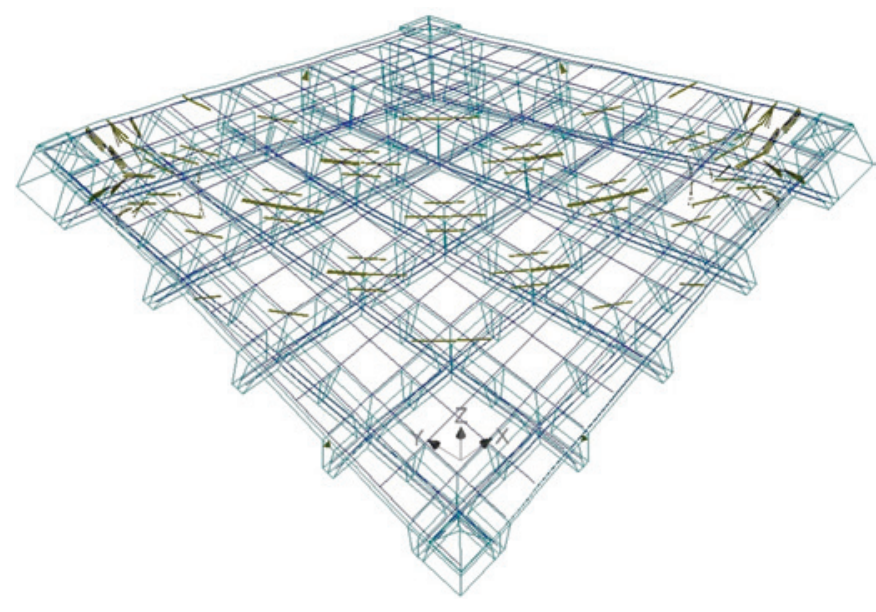

Figure 15

Cracks larger than $1 \mathrm{E}-4 \mathrm{~m}$ of the VL3A waffle slab cover, calculated with 22,278 finite elements and 34 loading steps

the rib cracks of the waffle slab VL3A. It is also possible to see, in Figure 14 and Figure 16, the twisting of the ribs.

Looking at Figure 13 and Figure 14 and considering that the painted cracks are larger than 3 hundredths of $\mathrm{mm}$ and compared with Figure 15 and Figure 16, whose painted cracks are larger than 1 tenth of $\mathrm{mm}$, it is noted that the cracks close to the rupture are very small. All this allows to infer that the tensile strength of the concrete is very high.

At the conclusion that the tensile strength was too high, several calculations with lower tensile strength were performed. It should be noted that this decrease in the tensile strength value was made by directly entering a new value for the $\mathrm{f}_{\mathrm{ctm}}$ in the program, since it allows this to be done. However, the program does not automatically correct the fracture energy when doing this direct intervention,

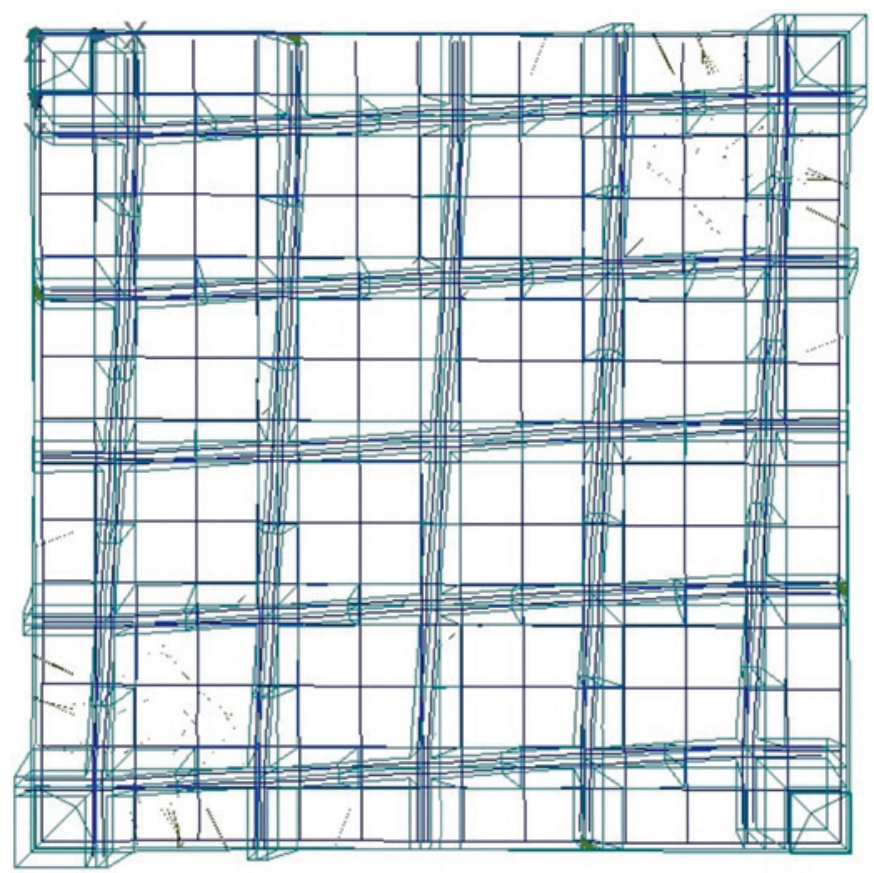

\section{Figure 16}

Cracks greater than $1 \mathrm{E}-4 \mathrm{~m}$ from the ribs of the VL3A waffle slab, calculated with 22,278 finite elements and 34 loading steps

which it should do, since this energy is the result of the integration of the constitutive relation diagram in the traction region.

In Figure 17 and Figure 18, the comparisons of experimental results are confronted with those obtained in the numerical analysis considering $\mathrm{f}_{\mathrm{cm}}=0,8 \mathrm{f}_{\mathrm{c}, \mathrm{cube}}$, with $\mathrm{f}_{\mathrm{ctm}}$ decreased by $50 \%$ of its value without correcting other mechanical property factors that are functions of $f_{c t m}$ directly or indirectly.
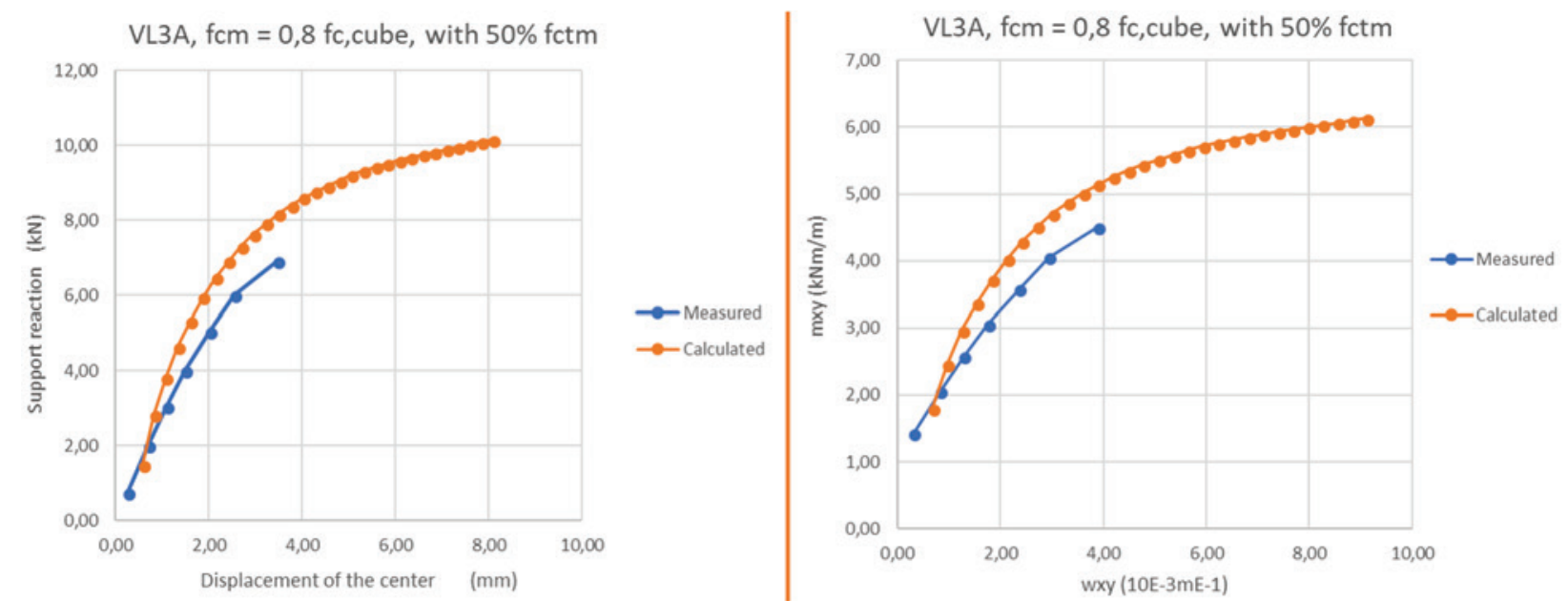

\section{Figure 17}

Comparison of experimental results versus numerical analysis of the VL3A model with mechanical properties calculated with $\mathrm{f}_{\mathrm{cm}}=0.8 \mathrm{f}_{\mathrm{c}, \mathrm{cube}}$, with $50 \%$ of the value of $\mathrm{f}_{\mathrm{ctm}}$ 
VL3B, fcm $=0,8 \mathrm{fc}$,cube, with $50 \% \mathrm{fctm}$

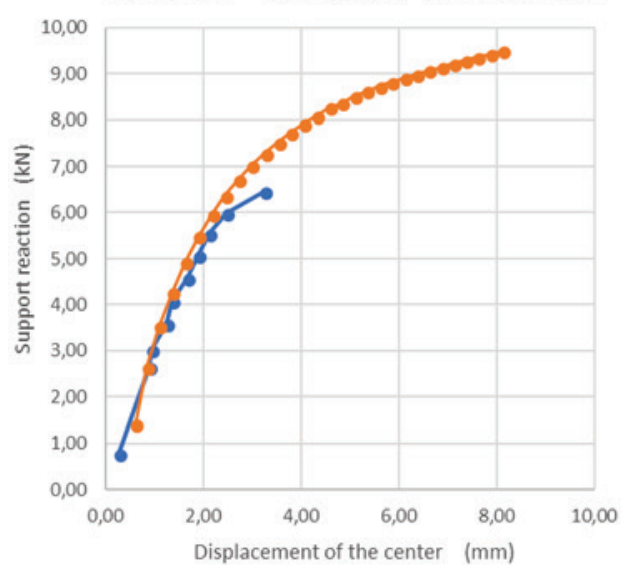

VL3B, fcm $=0,8 \mathrm{fc}$,cube, with $50 \% \mathrm{fctm}$

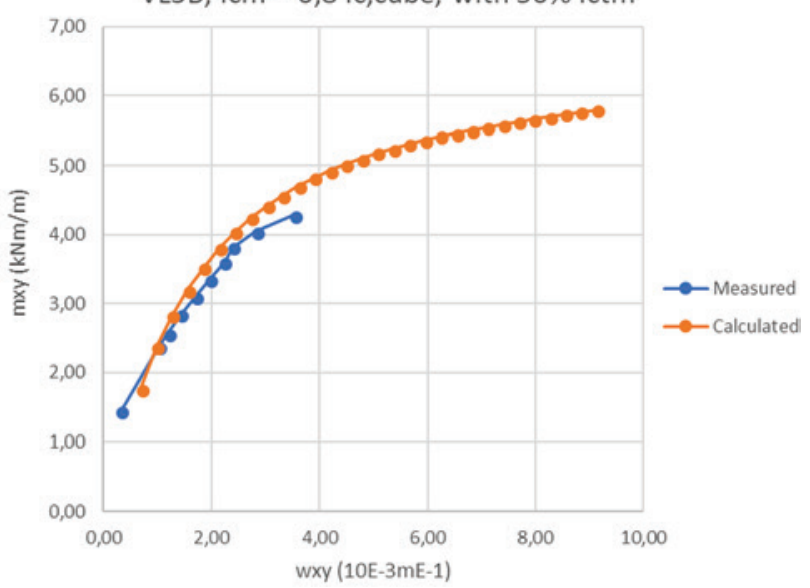

Figure 18

Comparison of experimental results versus numerical analysis of the VL3B model

with mechanical properties calculated with $\mathrm{f}_{\mathrm{cm}}=0.8 \mathrm{f}_{\mathrm{c}, \mathrm{cube}}$, with $50 \%$ of the value of $\mathrm{f}_{\mathrm{ctm}}$

Comparing the graphs of Figure 17 and Figure 18, the good convergence of the results of the numerical analysis with the experimental results is verified, using $50 \%$ of the value of $f_{c t m}$.

\section{Torsional tangent stiffness analyses}

After calibrating the numerical models with the experimental ones of the VL3A and VL3B waffle slabs, we can analyze the torsional tangent stiffness in the second graphs of Figures 17 and 18, referring to $\mathrm{w}_{\mathrm{xy}}$ versus $\mathrm{m}_{\mathrm{xy}}$.

However, it occurs that when one has a physical property that is linear, when measuring this property for several points, it will be difficult to obtain a perfectly linear arrangement for the measured points. If a second property is the derivative of this line, this second property will be greatly impaired by the non-linearity of the mea- sured data. However, the errors in this second physical property, which depends on the slope of the line, can be minimized by taking a linear regression on the data, that is, obtaining a line adjusted to the points. The precision of this adjustment is given by the coefficient of determination, $R^{2}$. The closer to 1 (one) $R^{2}$ is, more precise the simulation of the data by the straight obtained will be.

In the case of waffle slabs, the measured points should generate a saddle-shaped surface, see Figure 12. To calculate $w_{x y}$, which is also a derivative, (see Equation 3) without the large interferences of the small measurement errors (which make up parts of the uncertainties of any experiment), which would form angular points on this surface, it would be necessary to adjust a surface between the points. Since $\mathrm{w}_{\mathrm{xy}}$ is calculated with four-point data (see Equation 3), it already has an error minimization similar to the moving average technique. However, since the minimization of $\mathrm{w}_{\mathrm{xy}}$ errors is not perfect, the measu-
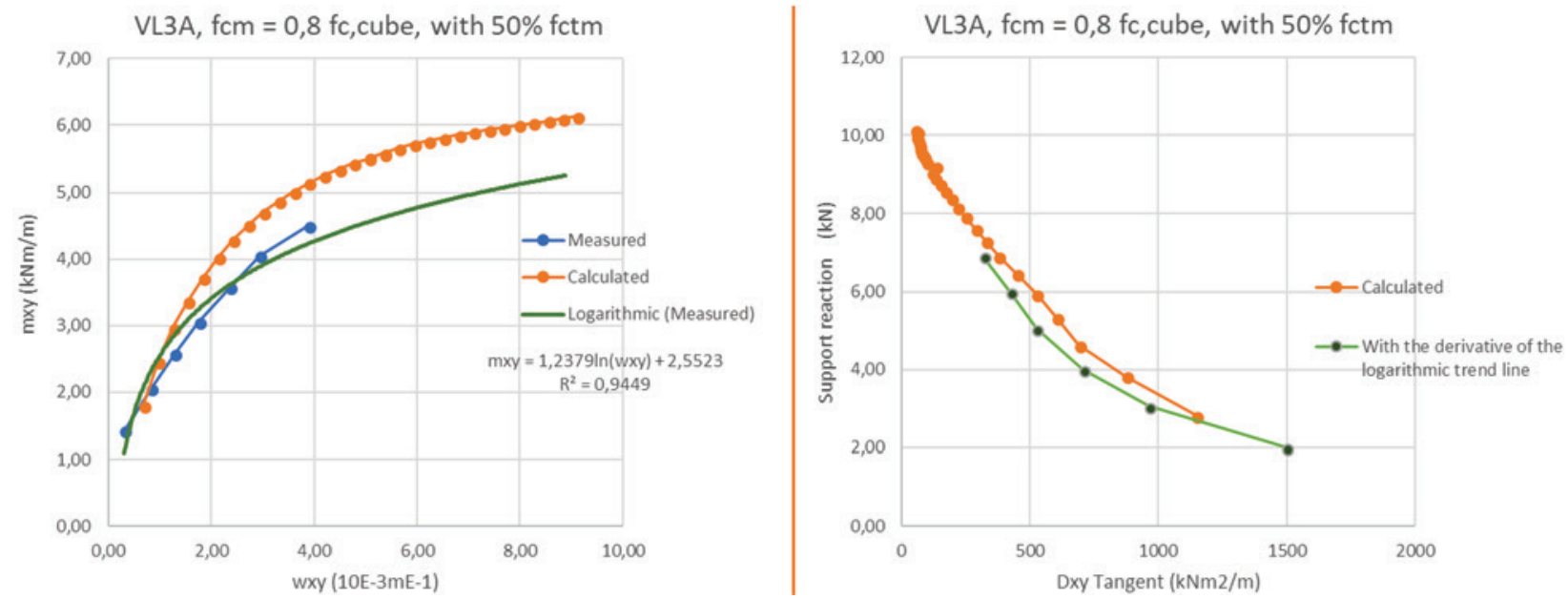

Figure 19

Calculation of Dxy by means of an adjusted logarithmic curve for the model VL3A with mechanical properties calculated with $\mathrm{f}_{\mathrm{cm}}=0.8 \mathrm{f}_{\mathrm{c}, \text { cube }}$ and $50 \%$ of value of $\mathrm{f}_{\mathrm{ctm}}$ 
red data will not form a perfect curve of $\mathrm{w}_{\mathrm{xy}}$ versus $\mathrm{m}_{\mathrm{xy}}$. This curve will have angular points that will cause large variations in the derivative that is used to calculate $D_{x y}$ tangent, since the derivative is more sensitive to the errors than the initial function.

The sensitivity of the derivatives to small errors in the function that originates it, also occurs in numerical methods, because in the finite element method the tensions, which are functions of deformations, and the latter are derived from the displacements, have much larger errors than the displacements that are the initial functions.

All this shows how the derivative is sensitive to small errors. However, for the data measured in the experimental trials of the waffle slabs, it is only necessary to adjust a curve in the graph of $w_{x y}$ versus $m_{x y}$ and calculate $D_{x y}$ with the derivative of that fitted curve. Several tests were performed with curve adjustments made available by Excel, including taking into consideration the extrapolation of data up to the limit of rupture calculated in the numerical analysis. It was found that this extrapolation is important because the polynomial functions adjustments may be good in the data range, but they give absurd results for points beyond the measured data, since these functions have several concavities and convexities depending on the adopted degree. The function that best fitted the data of $\mathrm{w}_{\mathrm{xy}}$ versus $\mathrm{m}_{\mathrm{xy}}$, resulting in an $\mathrm{R}^{2}$ close to 1 (one) and that showed good results for extrapolations beyond the measured data, was the logarithmic function.

Thus, with this logarithmic function, $D_{x y}$ can be determined by means of the derivative of this function. As the adjusted logarithmic function does not have angular points, the $D_{x y}$ values will not change abruptly due to small measurement errors, which occur naturally in experimental data.

Finally, comparing the values of the graph of experimental $D_{x y}$ tangent, calculated with the derivative of the adjusted logarithmic function, with the $D_{x y}$ tangent graph obtained from the numerical analysis, a good agreement between the two can be observed. This agreement of the experimental with the numerical one in the graph of $D_{x y}$ tangent, is seen in Figure 19 and Figure 20. With the confirmation of the numerical analysis data, with extrapolation of the logarithmic function, one can use numerical data reliably to in- fer tangent torsional rigidity in advanced situations such as rupture. In the second graphs, shown in Figures 19 and 20, rigidity tangent to the twist $D_{x y}$ versus support reaction, it is demonstrated, by means of the numerical analysis curve, that the torsional tangent rigidity decreases $95.4 \%$ for the VL3A model and $94.8 \%$ for the VL3B model, in relation to the initial tangent stiffness, until the charge of rupture (reaction), showing a great loss of rigidity tangent to the twist until rupture. However, in service limit states, the structures work partially in stage I and partially in stage II, with loads reaching about one-third of their capacity. At this load level the torsional tangent rigidity decreases, according to numerical analysis data, $13.3 \%$ for the VL3A model, Figure 19 , and $15.0 \%$ for the VL3B model, Figure 20 , in relation to the initial tangent stiffness. It is evidenced that at service level, the rigidity tangent to the torsion of the waffle slab remains high, close to the initial values, and consequently contributes strongly to the rigidity of the structure.

\section{Conclusions}

Numerical analysis of two waffle slabs of reinforced concrete was carried out to investigate the rigidity tangent to torsion, by means of comparisons of the numerical analysis with results of experimental tests, using calculations made in the ATENA program, at the Faculty of Science and Technology of the New University of Lisbon. The numerical analyses were carried out in the non-linear physical and geometric regime with the finite element method, considering the various properties of the concrete, such as tensile strength and fracture energy. After the initial calibration, a logarithmic function was fitted to the experimental data to calculate the torsion tangent rigidity and to extrapolate the results so as to compare them with the numerical analysis, validating the calculated results.

It was concluded that, for waffle slabs of reinforced concrete near the rupture, the rigidity tangent to the torsion should be $5 \%$ of the rigidity tangent to the initial torsion. Concrete is already in an advanced cracking process, but the three-dimensional confinement of the concrete and steel system still guarantees this level of rigidity.
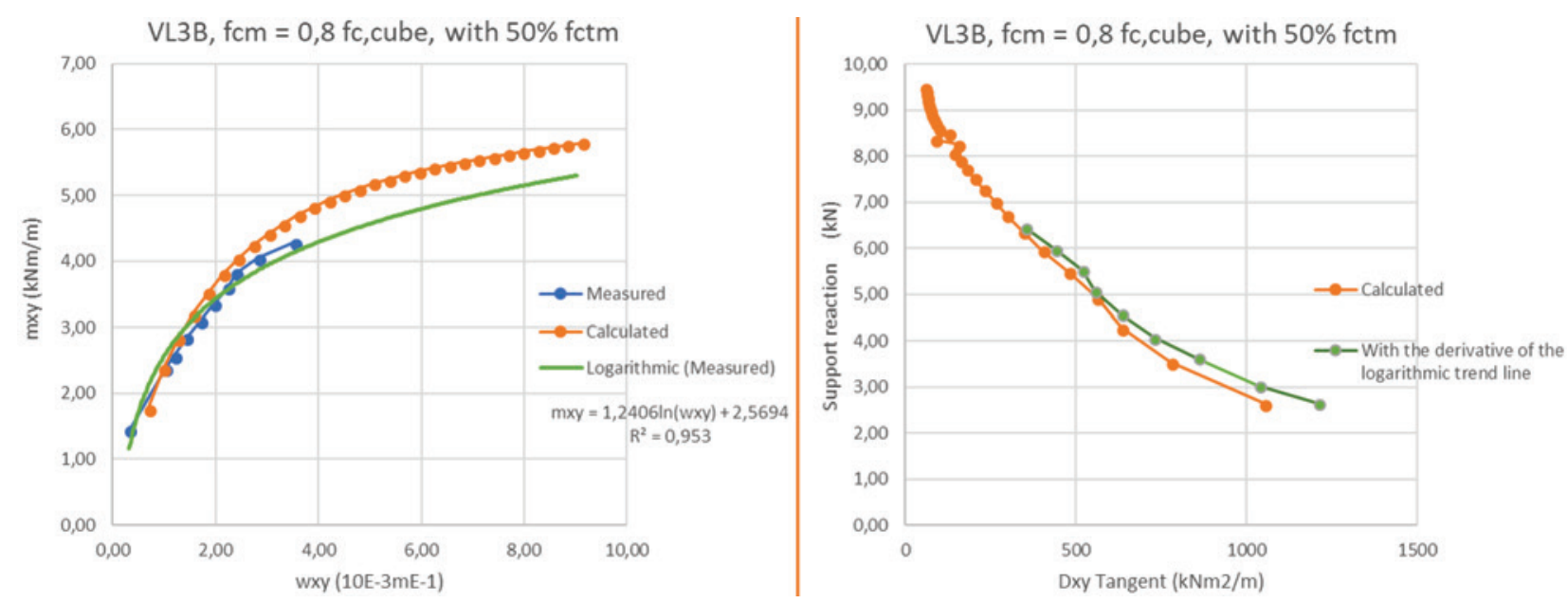

\section{Figure 20}

Calculation of Dxy by means of an adjusted logarithmic curve for the model VL3B with mechanical properties calculated with $f_{c m}=0.8 f_{c, \text { cube }}$ and $50 \%$ of value of $f_{c t m}$ 
For waffle slabs of reinforced concrete, in service, considering one-third of the total break load, the rigidity tangent to the twist should be $85 \%$ of the rigidity tangent to the initial twist. This is because the model as a whole is part of stage I and part of stage II and also because of the three-dimensional confinement of the reinforced concrete system, which results, in this situation, in a great rigidity tangent to the twist.

This great torsional tangent rigidity in service is another parameter that guarantees the structural efficiency of the waffle slabs and can be used in the most diverse applications of structural engineering.

\section{Acknowledgment}

I am grateful to the Faculty of Science and Technology of the New University of Lisbon, Lisbon-Portugal, especially the Associate Professor Válter J. G. Lúcio.

\section{References}

[1] ALBUQUERQUE, A. T. Análise de alternativas estruturais para edifícios em concreto armado. Dissertação de Mestrado. Escola de Engenharia de São Carlos. Universidade de São Paulo. São Carlos, 1999.

[2] NUNES, C. C. e LIMA, L. C. P. Comparação entre os esforços em pilares de edifício alto calculados no regime elástico linear com os calculados no regime elástico não linear geométrico. Congresso do IBRACON, Fortaleza, 2000.

[3] NUNES, C. C. Análise não linear geométrica de pórtico espacial com dependência generalizada entre deslocamentos. Tese D.Sc., Engenharia Civil, COPPE/UFRJ, Rio de Janeiro-RJ, 1998.

[4] NUNES, C. C.; SORIANO, H. L. and VENANCIO FILHO, F. Geometric non-linear analysis of space frame with rotation greater than $90^{\circ}$, with Euler angles and quasi-fixed local axes system. International Journal of Non-Linear Mechanics. v. 38, p. 1195-1204, 2003.

[5] NUNES, C. C. Dependência linear generalizada entre deslocamentos de modelos reticulados, placas e cascas. Tese M.Sc. Engenharia Civil, COPPE/UFRJ, Rio de Janeiro-RJ, 1994.

[6] SORIANO, H. L. e NUNES, C. C. Generalized linear relationship among displacements of frame structures. Computers \& Structures. v. 57, p. 439-445, 1995.

[7] LÚCIO, V. J. G. Waffle Slab Structures Under Vertical and Horizontal Loading. (Estruturas de Lajes Fungiformes Nervuradas sob Acções Verticais e Horizontais.) Tese de Doutoramento. Universidade Técnica de Lisboa. Instituto Superior Técnico. Lisboa, setembro de 1991.

[8] ASSOCIAÇÃO BRASILEIRA DE NORMAS TÉCNICAS ABNT NBR 6118:2014 - Projeto de estruturas de concreto - Procedimento. ISBN 978-85-07-04941-8. 2013.

[9] GALEB, A. C. and ATIYAH, Z. F. Optimum design of reinforced concrete waffle slabs. International Journal of Civil and Structural Engineering. ISSN 0976 - 4399. Volume 1, No 4, 2011.

[10] STRAMANDINOLI, J. S. B. e LORIGGIO, D. D. Lajes nervuradas: Cálculo dos esforços e deslocamentos usando o processo de analogia de grelha. V Simpósio EPUSP sobre Estruturas de Concreto, 2003a.
[11] STRAMANDINOLI, J. S. B. e LORIGGIO, D. D. Estudo da rigidez à torção para a aplicação do processo de analogia de grelha em lajes maciças. V Simpósio EPUSP sobre Estruturas de Concreto, 2003b.

[12] ARAÚJO, J. M. Considerações sobre a rigidez à torção das lajes nervuradas de concreto armado. Teoria e Prática na Engenharia Civil, n.7, p.1-8, Setembro, 2005.

[13] ARAÚJO, J. M. A rigidez equivalente das lajes nervuradas de concreto armado. Teoria e Prática na Engenharia Civil, $n$. 8, p. 1-9, Abril de 2006.

[14] RECALDE, B. R. B.; GASTAL, F. P. S. L.; BESSA, V. R. D'A; SCHWETZ, P. F. Numerical analysis of waffle slabs in flexure considering the effects of concrete cracking. IBRACON Structures and Materials Journal, 2015, vol. 8, $\mathrm{n}^{\circ} 2$.

[15] LIMA, M. V. A.; LIMA, J. M. F.; LIMA, P. R. L. Finite Difference Energy Method for nonlinear numerical analysis of reinforced concrete slab using simplified isotropic damage model. IBRACON Structures and Materials Journal, 2014, vol. $7, n^{\circ} 6$.

[16] TAVARES, A. J.; BARBOSA, M. P.; BITTENCOURT, T. N.; LORRAIN, M. Bond steel-concrete: simulation analysis of the pull-out tests and APULOT using the program ATENA. IBRACON Structures and Materials Journal, 2014, vol. 7, $\mathrm{n}^{\circ} 1$.

[17] PARENTE JR, E.; NOGUEIRA, G. V.; MEIRELES NETO, M.; MOREIRA, L. S. Material and geometric nonlinear analysis of reinforced concrete frames. IBRACON Structures and Materials Journal, 2014, vol. 7, n 5.

[18] MARASCA, C. Z. S.; BITTENCOURT, E.; BESSA, V. M. R. D. Modelling of fracture problems in quasi-brittle materials by the E-FEM. IBRACON Structures and Materials Journal, 2018, vol. 11, n² 2.

[19] ARAÚJO, J. M. Estruturas de Concreto - A resistência à tração e energia de fratura do concreto. Número 2. Editora DUNAS. ISSN 1519-4086. Rio Grande, julho de 2001.

[20] FERNÁNDEZ-CANTELI, A.; CASTAÑÓN, L.; NIETO, B.; LOZANO, M; HOLUŠOVÁ, T. and SEITL, S. Determining fracture energy parameters of concrete from the modified compact tension test. Frattura ed Integrità Strutturale, 30 (2014) 383-393; DOI: 10.3221/IGF-ESIS.30.46. 2014.

[21] BAZANT, Z. P. and KAZEMI, M. T. Determination of fracture energy, process zone length and brittleness number from size effect, with application to rock and concrete. International Journal of Fracture 44: 111-131, 1990.

[22] ABDALLA, H. M. and KARIHALOO, B. L. Determination of size-independent specific fracture energy of concrete from three-point bend and wedge splitting tests. Magazine of Concrete Research, 55, №. 2, April, 133-141, 2003.

[23] LEE, J. and LOPEZ, M. M. An Experimental Study on Fracture Energy of Plain Concrete. International Journal of Concrete Structures and Materials Vol.8, No.2, pp.129-139, June 2014.

[24] fib - CEB-FIP - Model Code for Concrete Structures 2010 - Prepared by Special Activity Group 5. Fédération Internationale du Béton / International Federation for Structural Concrete (fib). 2013.

[25] SILVA NETO, C. P. Modelagem da fratura do concreto armado por meio de interfaces coesivas. Dissertação de Mestrado. Universidade Federal do Rio Grande do Sul. Escola de 
Engenharia. Programa de Pós-Graduação em Engenharia Civil. Porto Alegre, Brasil, 2015.

[26] ČERVENKA CONSULTING S.R.O. Written by: Červenka, Vladimír; Jendele, Libor and Červenka, Jan. ATENA Program Documentation - Part 1 - Theory. Prague, Czech Republic, May, 2016

[27] ČERVENKA CONSULTING S.R.O. Written by: Červenka, Jan; Procházková, Zdenka and Sajdlová, Tereza. ATENA Program Documentation - Part 4-2 - Tutorial for Program ATENA 3D. Version 5.1.3. Prague, Czech Republic, September, 2016.

[28] ČERVENKA CONSULTING S.R.O. Written by: Červenka, Vladimír and Červenka, Jan. ATENA Program Documentation - Part 2-2 - User's Manual for ATENA 3D. Version 5.1.3. Prague, Czech Republic, June, 2016.

[29] NORMA PORTUGUESA - EUROCÓDIGO 2 - Projeto de estruturas de betão. NP EN 1992-1-1 2010. Edição Março de 2010 